\title{
Evaluation of Factors Affecting the Use of the Central Physician Appointment System
}

\author{
Selma Pekgör,' Mehmet Ali Eryılmaz,' İbrahim Solak, ${ }^{1}$ Ahmet Pekgör² \\ Hümeyra Yaka, ${ }^{1}$ Ibrahim Fuat Kayıhan Kaya, ${ }^{1}$ Dilek Korkusuz, ${ }^{1}$ \\ Seher Mercan, ${ }^{1}$ Koray Bolatkale, ${ }^{1}$ Mehmet Koç3
}

'Department of Family Medicine, University of Health Sciences, Konya

Training and Research Hospital, Konya, Turkey Department of Statistics, Necmettin Erbakan University, Ahmet Keleşoğlu Education Faculty, Konya, Turkey

${ }^{3}$ Department of Radiation

Oncology, University of Health

Sciences, Konya Training and

Research Hospital, Konya, Turkey

Submitted: 02.08.2017

Accepted: 25.09.2017

Correspondence: Selma Pekgör Konya Eğitim ve Araştırma Hastanesi, Aile Hekimliği Kliniği, Konya, Turkey E-mail: selmapekgor@outlook.com

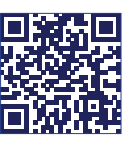

Keywords: Central Physician Appointment System; Hello I82; patient satisfaction; wait time.

\begin{abstract}
Objective: The aim of this study was to investigate the frequency of use of the Central Physician Appointment System (CPAS) in a Konya hospital and the factors affecting use.
\end{abstract}

Methods: A total of 7187 people who were admitted to the outpatient clinics of the hospital and had completed an examination between January 20 and February 28, 2017 were included in the study. Face-to-face interviews were performed with the patients.

Results: Of all the patients, $49.9 \%$ made their appointment via CPAS, and $47.4 \%$ made an appointment from a kiosk. CPAS usage was higher among white-collar workers than tradesmen, laborers, housewives, or retirees $(p<0.001)$. As education level and monthly income level increased, the use of CPAS also increased $(p<0.00 \mathrm{I})$. CPAS was also used more by those who lived in the center of Konya than by those who lived in surrounding rural areas $(\mathrm{p}<0.00 \mathrm{I})$. The patient satisfaction rate was $89.4 \%$.

Conclusion: In order to increase the use of CPAS, new strategies should be developed targeting residents of rural areas and those of lower socioeconomic status. Existing public service announcements and promotional leaflets should also be disseminated.

\section{INTRODUCTION}

One of the most important healthcare objectives is to ensure that every sector of society has equal access to and benefit of all healthcare services offered, irrespective of their economic power. ${ }^{[1,2]}$

The Ministry of Health has implemented the Health Transformation Project to make easy access to health services more effective and efficient. The Health Transformation Project aims to consistently offer citizens effective and easily accessible health services. ${ }^{[3]}$ One of the most important components of this project is the Central Physician Appointment System (CPAS). Citizens can now make an appointment with their preferred hospital, oral and dental health center, or family physician at a convenient time using the Hello 182 call center or its website, or through the
CPAS mobile application system. ${ }^{[3,4]}$

The pilot program was implemented in Erzurum and Kayseri province in 2010 , and it was put into practice all over the country in 2012 . In 20I3, family physicians were added to the project, and the reach of CPAS was extended. In 2014, the e-Pulse Personal Health Record System, which is a public service, was integrated with CPAS. In 2014, access to CPAS was also made available through the e-State portal. In 2016, the use of PIN codes was introduced to protect personal data and facilitate easy access to the health system. Citizens were then able to access the system using their confidential e-State PIN codes.

The aim of the CPAS project is to shorten waiting periods at hospitals and polyclinics so as to provide a more relaxed and quiet setting for everyone, to use physician staff time more efficiently, and to enable citizens to manage their 
time better. ${ }^{[3,4]}$ This is the only national physician appointment system in the world managed from a single center ${ }^{[3]}$

Today, health services are often dealt with from the perspective of business administration. Attracting the attention of more patients, increasing the satisfaction of patients, and ensuring that patients can access preferred institutions are targets of health management authorities. [5] The use of technology in health services and the increase in demand for high quality healthcare services has led to changes in the delivery of health services. ${ }^{[6]}$ However, healthcare services are produced and received at the same time, there is no inventory as in other businesses, which complicates the measurement of product quality. [7] Patient satisfaction constitutes a substantial part of the quality of health service. ${ }^{[8]}$ From the perspective of the patient, satisfaction is defined as the fulfillment of desires, expectations, and needs according to sociocultural values, while dissatisfaction is perceived as an unfavorable difference between the patient's expectations, and the service provided. ${ }^{[5,9,10,11]}$ Patient satisfaction is determined by 2 factors. The first is the patient's expectations, which consist of scientific, administrative, and behavioral characteristics that the patients want to see in a health institution. These expectations vary depending on age, gender, educational level, and the sociocultural characteristics of the individuals. The second factor is the perceptions of the patients about the service they received. Factors affecting patients' perceptions vary according to the sociocultural characteristics of patients, and their past experiences with the specific health institution. ${ }^{[12]}$

The aim of this study was to determine how frequently CPAS was used by ambulatory patients, the factors affecting the patients' choice whether or not to use CPAS, and the satisfaction level of the patients.

\section{MATERIAL AND METHODS}

The required ethical approvals were obtained. Ambulatory patients who presented at the outpatient clinics of the hospital between January 20, 2017 and February 28, 2017 and volunteered to participate in our survey after completion of their medical examinations were included in our study. A power analysis determined that a sample size of 6319 patients would have a statistical power of $80 \%$ and a margin of error of 0.05 . The study was completed with the participation of 7187 patients. The hospital of the study provides ambulatory health service in nearly 50 disciplines. The participants were randomly chosen from patients examined in all outpatient clinics. Ten interviewers conducted daily surveys of patients whose examinations were completed between 9:00 am and 4:00 pm. The interviewers were volunteer medical profession students working as trainees in various clinics of the hospital trained by the author in charge of the survey. After a week of preliminary work, data collection began. The data were transferred to digital media by clinic residents. Patients aged $<18$ years, those who declined to complete the questionnaire, and cases with missing data were not included in the study.

The survey consisted of a sociodemographic characteristics form and a total of 18 questions concerning the use of CPAS. The questions concerned age, gender, marital status, profession, educational level, place of residence, monthly income, whether the patient knew of or had used CPAS before, the reason for not using CPAS, the method the patient used to make an appointment, why they chose this method, who made the appointment, whether the patient was examined by their preferred physician, the wait time before the examination, the method they will use for their next appointment, and if they were satisfied with the service provided.

After all of the questionnaire forms were collected, statistical analyses were performed and evaluated using IBM SPSS Statistics for Windows, Version 22.0 (IBM Corp., Armonk, NY, USA). A type I error of 0.05 was taken into consideration in the analyses. Descriptive statistics for continuous variables were expressed using mean $\pm S D$, and descriptive statistics for categorical variables were presented as frequencies and percentages. Distribution analysis for normality was performed using the ShapiroWilk and Kolmogorov-Smirnov tests. For 2 independent samples with non-normal distribution, the Mann-Whitney $\cup$ test was applied, and for 3 or more independent samples, the Kruskal-Wallis test was used. A chi-square test of independence was employed to compare categorical data.

\section{RESULTS}

The sociodemographic characteristics of the patients examined are presented in Table I. The majority $(88.7 \%$; $n=6347$ ) of the patients had heard of CPAS, and $78.8 \%$ $(n=5628)$ had used it at least once. In all, $27.6 \%(n=543)$ of the patients reported that they did not use the system because they didn't know how to access it by phone or Internet, they didn't feel the need to use it $(24.9 \%$; $n=489)$, found it impractical (I7.8\%; $n=35 \mathrm{I})$, they decided to seek an examination at the last minute $(13.4 \% ; n=264)$, they cited the fact that CPAS was not free of charge $(5.8 \%$; $\mathrm{n}=1 \mid 4$ ), and that the appointment schedule of their preferred physician was full (Table 2).

In response to the question, "Which method did you use today to get an appointment?" the results were $47.4 \%$ used a kiosk ( $n=3393), 49.9 \%$ used CPAS ( $n=3574 ; 35.7 \%$ by the Hello 182 phone line, $14.2 \%$ via the Internet), and $2.7 \%$ through an acquaintance working in the hospital $(n=191)$. The reason for using this method was (I) It is easy to get an appointment number from a kiosk (64.3\%), (2) I decided to get medical care at the last minute (I7.9\%), (3) 
Table I. Sociodemographic characteristics

\begin{tabular}{|c|c|c|}
\hline Age & $\%$ & $\mathbf{n}$ \\
\hline \multicolumn{3}{|l|}{ Gender } \\
\hline Female & 62.9 & 4514 \\
\hline Male & 37.1 & 2666 \\
\hline \multicolumn{3}{|l|}{ Marital status } \\
\hline Married & 71.8 & 5150 \\
\hline Single & 22.4 & 1609 \\
\hline Widow/widower & 4.3 & 306 \\
\hline Divorced & 1.5 & 111 \\
\hline \multicolumn{3}{|l|}{ Education level } \\
\hline Primary school & 53.9 & 3794 \\
\hline High school & 27.4 & 1931 \\
\hline University and higher & 18.7 & 1312 \\
\hline \multicolumn{3}{|l|}{ Occupation } \\
\hline Housewife & 46.3 & 3283 \\
\hline White-collar worker & 18.6 & 1320 \\
\hline Laborer & 12.1 & 861 \\
\hline Retiree & 9.8 & 693 \\
\hline Unemployed & 7.2 & 506 \\
\hline Tradesman/self-employed & 6.0 & 428 \\
\hline \multicolumn{3}{|l|}{ Monthly income (Turkish lira) } \\
\hline$<1300$ & 34.0 & 2393 \\
\hline $1300-3000$ & 50.0 & 3525 \\
\hline $3000-5000$ & 13.5 & 950 \\
\hline$\geq 5000$ & 2.5 & 179 \\
\hline \multicolumn{3}{|l|}{ Place of residence } \\
\hline Konya center & 72.2 & 5176 \\
\hline District & 18.4 & 1319 \\
\hline Village/town & 6.0 & 431 \\
\hline Another city & 3.4 & 247 \\
\hline
\end{tabular}

CPAS indicated that my physician had no appointments available (6. I\%), (4) I didn't know any other method of getting an appointment (I3\%), and (5) I knew that it was free of charge (2.4\%). Among the patients who requested an appointment through an acquaintance working at the hospital, $60.2 \%$ stated that they did so because it was easier, $17.2 \%$ replied that they had decided to get medical care at the last minute, $10.2 \%$ said that they didn't know of any other method, and $4.3 \%$ said because it was free of charge.

When asked who made their appointment, $69.0 \%$ $(n=4953)$ responded that they had done it themselves, $26.8 \%(n=1926)$ said a relative, $2.0 \%(n=142)$ replied that an acquaintance working at the hospital made it for them, I. $2 \%(n=89)$ said that a hospital employee helped them do it and $1.0 \%(n=70)$ responded that they had asked other
Table 2. Patient preferences for CPAS and influencing factors

\begin{tabular}{lll}
\hline Survey questions & $\%$ & $\mathbf{n}$ \\
\hline
\end{tabular}

Have you heard of CPAS?

$\begin{array}{lll}\text { Yes } & 88.7 & 6374 \\ \text { No } & 11.3 & 809\end{array}$

Have you ever used CPAS?

$\begin{array}{lll}\text { Yes } & 78.8 & 5628 \\ \text { No } & 21.2 & 1510\end{array}$

What is your reason for not using CPAS?

It is not practical

$17.8 \quad 351$

It is not free of charge

$10.5 \quad 206$

I don't know how to use a phone or

the Internet

$27.6 \quad 543$

I decided to get examined at the

last minute

$13.4 \quad 264$

I don't feel the need to use CPAS

$24.9 \quad 489$

No appointment time was available

on the system

$5.8 \quad 114$

Today which method did you use to

make an appointment?

Kiosk

$47.4 \quad 3393$

CPAS

$49.9 \quad 3574$

An acquaintance working at the

hospital made it for me

$2.7 \quad 191$

Who made your appointment?

I did

$69.0 \quad 4953$

A relative

$26.8 \quad 1926$

A hospital employee

$1.2 \quad 89$

An acquaintance working at the hospital

$2.0 \quad 142$

I asked another patient to help

$1.0 \quad 70$

How long did you wait before seeing a doctor?

$\begin{array}{lcc}<15 \text { min } & 46.5 & 3337 \\ 15-30 \mathrm{~min} & 29.4 & 2111 \\ 30-60 \mathrm{~min} & 12.7 & 909 \\ 1-2 \text { hrs } & 7.3 & 521 \\ >2 \text { hrs } & 4.1 & 291\end{array}$

Are you satisfied with the service you received?

Yes

$89.4 \quad 6391$

No

$10.6 \quad 754$

What method will you use to make your next appointment?

$\begin{array}{lcc}\text { Kiosk } & 26.7 & 1913 \\ \text { CPAS } & 70.9 & 507 \text { I } \\ \text { An acquaintance working at the hospital } & 2.0 & 142 \\ \text { I will ask another patient to help } & 0.4 & 31\end{array}$

CPAS: Central Physician Appointment System. 
patients for help. Most ( $91.6 \%$; $=6552$ ) of the patients indicated that they were able to get an appointment with and be examined by their preferred physician. A few (8.4\%; $n=596)$ patients stated that they couldn't be seen by their preferred physician, but were examined by another doctor. Every patient who had an appointment number was examined by a physician (Table 2 ).

The participants were also asked how long they waited to be examined, and the replies were less than 15 minutes, $46.5 \%(n=3337)$; 15 to 30 minutes, $29.4 \%(n=21 \mathrm{II}) ; 30$ to 60 minutes, $12.7 \%(n=909)$; I to 2 hours, $7.3 \%(n=521)$; and more than 2 hours, $4.1 \%(n=291)$. In response to a question inquiring if they felt the physician had spent enough time with them, $89.4 \%(n=6391)$ responded affirmatively, while $10.6 \%(n=754)$ of the patients responded negatively. Replies to the question "How will you make your next appointment?" were $26.7 \%(n=1913)$ would use a kiosk, 70.9\% $(n=507 \mathrm{I})$ would use CPAS, $2.0 \%(n=142)$ would ask an acquaintance working at the hospital, $0.4 \%$ $(n=31)$ said that they would ask the help of another patient.

Eighty percent $(n=3585)$ of the female participants and $76.9 \%(n=2039)$ of the male patients indicated that they had previously used CPAS at least once $(p=0.002)$ (Table $3)$. In all, $65.6 \%(n=2955)$ of the female and $74.8 \%(n=1994)$ of the male patients made their own appointments, and there was a statistically significant difference between the male and female patients $(p<0.001)$. When asked how they would make their next appointment, $72.9 \%(n=3276)$ of the female patients and $67.3 \%(n=1789)$ of the male patients indicated that they would use CPAS. Female patients chose CPAS more often than male patients $(p<0.001)$.

When responses were analyzed according to occupation, it was observed that $87.7 \%(n=2876)$ of housewives, $93.9 \%(n=1239)$ of white-collar workers, $87.5 \%(n=753)$ of laborers, $82.4 \%(n=570)$ of retirees, $90.3 \%(n=456)$ of the unemployed, and $91.6 \%(n=392)$ of tradesmen had heard of CPAS. There were statistically significant differences between occupations ( $\mathrm{p}<0.00 \mathrm{I})$. In addition, $86.3 \%$ $(n=1133)$ of white-collar workers, $78.6 \% \quad(n=335)$ of tradesmen, $78.2 \%(n=2545)$ of housewives, $78.0 \%(n=384)$ of the unemployed, $77.3 \%(n=659)$ of laborers, and $70.3 \%$ $(n=485)$ of retires had used CPAS at least once. Whitecollar workers had used the CPAS appointment system most frequently. Statistically significant differences were seen between occupations $(p<0.00 I)$ (Table 3).

Responses also revealed that among those with a primary school education, $46.0 \%(n=1737)$ used CPAS to make their appointment, $5 \mathrm{I} .4 \%(\mathrm{n}=1942)$ a kiosk, and $2.3 \%$ $(n=44)$ had asked the help of an acquaintance working at the hospital. For graduates of high school the respective figures were $58.6 \%(n=767), 38.4 \%(n=502)$, and $3.0 \%$ $(n=39)$. CPAS use increased and kiosk use decreased in
Table 3. Demographic characteristics of the patients who used CPAS at least once

\begin{tabular}{|c|c|c|c|}
\hline & $\%$ & $\mathrm{n}$ & $\mathrm{P}$ \\
\hline \multicolumn{4}{|l|}{ Gender } \\
\hline Women & 80.0 & 3585 & 0.002 \\
\hline Men & 76.9 & 2039 & \\
\hline \multicolumn{4}{|l|}{ Marital status } \\
\hline Married & 79.6 & 4070 & $<0.001$ \\
\hline Single & 79.5 & 1273 & \\
\hline Wîdow/widower & 67.3 & 204 & \\
\hline Divorced & 67.9 & 74 & \\
\hline \multicolumn{4}{|l|}{ Education level } \\
\hline Primary school & 75.5 & 2844 & $<0.001$ \\
\hline High school & 81.0 & 1550 & \\
\hline University and higher & 87.0 & 1136 & \\
\hline \multicolumn{4}{|l|}{ Occupation } \\
\hline Housewife & 78.2 & 2545 & $<0.001$ \\
\hline White-collar worker & 86.3 & 1133 & \\
\hline Laborer & 77.3 & 659 & \\
\hline Retiree & 70.3 & 485 & \\
\hline Unemployed & 78.0 & 384 & \\
\hline Tradesman/self-employed & 78.6 & 335 & \\
\hline \multicolumn{4}{|l|}{ Monthly income (TL) } \\
\hline$\leq 1300$ & 73.3 & 1734 & $<0.001$ \\
\hline $1300-3000$ & 79.8 & 2802 & \\
\hline $3000-5000$ & 88.3 & 833 & \\
\hline$\geq 5000$ & 85.5 & 153 & \\
\hline \multicolumn{4}{|l|}{ Place of residence } \\
\hline Konya city center & 80.5 & 4140 & $<0.001$ \\
\hline Another city & 77.7 & 192 & \\
\hline District & 77.6 & 1009 & \\
\hline Village/town & 63.6 & 274 & \\
\hline
\end{tabular}

CPAS: Central Physician Appointment System; TL: Turkish lira.

parallel with education level $(p=<0.001)$.

Only $57.9 \%(n=2197)$ of primary school graduates made their own appointment, while $80.7 \%(n=1556)$ of high school graduates did, and $80.7 \%(n=1556)$ of university graduates did, revealing a statistically significant difference $(p<0.001)$. Patients with more formal education asked for the help of other patients or hospital personnel less frequently. Similarly, patients with a higher monthly income more often made their own appointment and less often required assistance. A statistically significant intergroup correlation was detected $(p<0.001)$. When asked how they would make their next appointment, $69.3 \%$ $(n=2580)$ of primary school graduates, $71.3 \%(n=1370)$ of 
high school graduates, and $78.2 \%(n=1204)$ of university graduates replied that they would use CPAS. A statistically significant correlation was found between education level and the preference to use CPAS $(\mathrm{p}<0.00 \mathrm{I})$.

In all, 83.6\% $(n=2000)$ of those with a monthly income less than minimum wage had heard of CPAS, $90.9 \%(n=3204)$ of the patients earning TL 1300-3000 per month, 93.4\% $(n=887)$ with an income of TL 3000-5000, and 91.1\% $(n=161)$ of those earning $\geq 5000$ monthly knew of the service. In terms of residence, $91.1 \%(n=47 \mid 4)$ of the patients living in the city center, $85.7 \%(n=|| 3 \mid)$ of those residing in the district, $70.6 \%$ of patients living in the surrounding villages and towns, and $86.2 \%(n=2 / 3)$ of those living in another city were aware of CPAS, with statistically significant differences between them $(p<0.00 I)$. Of those living in the city center, $80.5 \%(n=4 \mid 40)$ had used CPAS at least once, while the figure was $77.6 \%(n=1009)$ for patients living in the district, $63.6 \%(n=274)$ for patients living in nearby villages and towns, and $77.7 \%(n=192)$ of those living in another city $(\mathrm{p}<0.00 \mathrm{I})$ (Table 3$)$. Statistically significant differences were found between the groups.

Patients living in villages and towns most frequently made their appointment at a kiosk or asked the help of acquaintances working in the hospital. Patients living in the city center most often called the Hello 182 phone line, and patients living in another city most often used the Internet. A statistically significant difference was seen between groups $(p<0.00 \mathrm{I})$. For their next appointment, patients living in villages and towns preferred to use a kiosk or ask for assistance from an acquaintance working in the hospital or another patient, while those living in the city center most often indicated that they would use the CPAS alternative. There was a statistically significant difference between groups $(\mathrm{p}<0.001)$.

Of those using a kiosk for the current appointment, 89.3\% $(n=3022)$ were able to see the physician they hoped to, 94.0\% $(n=1032)$ of those who used CPAS saw their doctor of choice, and $91.0 \%(n=172)$ of those who made an appointment through an acquaintance working at the hospital were examined by their preferred physician. CPAS users were most able to make an appointment with their favored physician $(p<0.00 I)$.

Of the patients who made their appointment using the Internet, $87.0 \%(n=883)$ waited for less than 30 minutes, while $83.7 \%(n=2136)$ of those who used the Hello 182 phone line, $67 \%(n=2269)$ of those who used a kiosk, and $72.1 \%(n=137)$ of those made an appointment with the help of their acquaintance at the hospital did not wait for 30 minutes before seeing a doctor. The results indicated that $16.3 \%(n=550)$ of the patients who used a kiosk for their appointment, $9.8 \%(n=250)$ of the patients who called the Hello 182 phone line, $7.9 \%(n=883)$ of those who used the Internet, and $14.2 \%(n=27)$ of the patients who asked their acquaintances for help waited for 30 to 60 minutes to be seen. Furthermore, $13.7 \%(n=26)$ of those who made an appointment with the help of their acquaintance working at the hospital, $6.6 \%(n=167)$ of those who called Hello 182, 16.7\% $(n=454)$ of those who used a kiosk, and $5.1 \%(n=5 I)$ of those who used the Internet waited for more than I hour. According to our study, patients making an appointment through CPAS had the shortest wait time, and those preferring to use a kiosk or asking the help of an acquaintance had the longest wait before being examined. A statistically significantly difference was found between groups $(p<0.001)$.

A representative sample of patients was included for each of the 50 hospital departments. These departments were categorized as internal medicine, surgery, and subspecialties. When analyzing wait time by category, $76.3 \%(n=3270)$ of the internal medicine patients said that they waited less than 30 minutes to see a doctor, $76.9 \%(n=1685)$ of surgical patients, and $71.0 \%(\mathrm{n}=472)$ of subspecialty patients waited no more than half an hour. A total of $13.0 \%$ $(n=559)$ of the internal medicine patients, $10.7 \%(n=458)$ of surgical patients, and II.7\% $(n=256)$ of subspecialty patients waited for 30 to 60 minutes, and II.4\% $(n=249)$ of internal medicine patients, $13.8 \%(n=92)$ of surgical patients, and $15.2 \%(n=|0|)$ reported waiting for more than an hour before being examined. The subspecialty patients waited the longest for their examination. The difference was statistically significant $(p=0.004)$ (Table 4).

Among the internal medicine patients, 46.8\% $(n=1999)$ used CPAS to make their appointment, $56.1 \%(n=1227)$ of surgical patients, and $50.4 \%(n=338)$ of subspecialty patients used the system. The difference between categories was statistically significant $(p<0.00 I)$. Internal medicine patients were the most likely to use a kiosk to make their appointment (Table 4).

When asked about their satisfaction level, 89.4\% $(n=6391)$ of the patients indicated that they had sufficient time with the doctor, while $10.6 \%(n=754)$ of the patients were not satisfied with the length of their appointment. In all, 92.5\% of the internal disease patients, $95.6 \%$ of the family medicine patients, $76.5 \%$ of neurosurgery patients, $89.3 \%$ of dermatology patients, $86.7 \%$ of pediatric surgery patients, $91.4 \%$ of children's health and diseases patients, $89.3 \%$ of endocrinology patients, $84.5 \%$ of infectious disease patients, $92.2 \%$ of physical therapy and rehabilitation patients, $88.0 \%$ of gastroenterology patients, $91.4 \%$ of general surgery patients, $90.4 \%$ of thoracic surgery patients, $90.9 \%$ of ophthalmology patients, $84.1 \%$ of hematology patients, $83.8 \%$ of obstetrics and gynecology patients, $87.7 \%$ of cardiovascular surgery patients, $87.5 \%$ of cardiology patients, $89.3 \%$ of otorhinolaryngology patients, $89.8 \%$ of nephrology patients, $89.8 \%$ of neurology patients, $87.9 \%$ of orthopedics and traumatology patients, $91.7 \%$ of plastic 
Table 4. Patient satisfaction and preference for CPAS in subspecialties, internal medicine, and surgical categories

\section{Internal medicine}

(\%)

Appointment method

$$
\text { Kiosk }
$$

CPAS

Hospital employee

Wait time

$<30$ min

30-60 min

$>60$ min

Satisfaction rate
50.9

46.8

2.3

76.3

13.0

10.7

90.2
Surgery

(\%)
46.1

50.4

$3.1 \quad 3.4 \%$

$\begin{array}{ll}76.9 & 71.0\end{array}$

$11.7 \quad 13.8$

$11.4 \quad 15.2$

$88.0 \quad 89.3$ p

(\%)

CPAS: Central Physician Appointment System

and reconstructive surgery patients, $88.7 \%$ of psychiatry patients, $92.9 \%$ of rheumatology patients, $88.8 \%$ of medical oncology patients, $86.5 \%$ of urology patients, $97.4 \%$ of dentistry patients, and $94.9 \%$ of allergy and immunology patients were satisfied. By category, the overall patient satisfaction rate was $90.2 \%$ for internal medicine, $88.0 \%$ for surgery, and $89.3 \%$ for the subspecialties, with a statistically significant difference $(p=0.027)$ (Table 4).

\section{DISCUSSION}

Our study had a larger sample size than previous studies performed, numerous factors that could influence CPAS use were examined, and an analysis of the sociodemographic characteristics of the patients was also conducted. The results of our research indicated that $88.7 \%(n=6374)$ of the patients had heard of CPAS before, and that $78.8 \%$ $(n=5628)$ had used it at least once. In a similar study performed in Ankara in 2016,83.3\% of the patients reported that they had been informed about CPAS, and $80 \%$ of them had used the system at least once. ${ }^{[4]}$

When asked why they used a kiosk to make their appointment, $64.3 \%$ of those patients replied that it was easy, $17.9 \%$ responded that they had decided to be examined at the last minute, and $6.1 \%$ used a kiosk because the appointment list of their preferred physician displayed on CPAS was full. In addition, 6.1\% had not known of any other method, and $4.7 \%$ had chosen to use a kiosk because there was no cost. Among the patients who used CPAS, $93.8 \%$ said because it was easy, $2.4 \%$ said because it was free of charge, and I.3\% had not known of another method . In all, $60.2 \%$ of the patients who asked their acquaintances for an appointment indicated that it was an easy method to use, while $17.2 \%$ of them stated that they had decided to see a doctor at the last moment. Another $10.2 \%$ said they had not known of any other method, and
4.3\% preferred this means because there was no cost involved. It is noteworthy that the percentage of patients who used kiosk, asked the help of an acquaintance at the hospital, those who made a last minute decision, and those who said they had not known of another method of making an appointment was greater than the percentage of those who had used CPAS. A large percentage of the patients who used CPAS, 93.8\%, reported that it was easier to use than other methods.

The patients were also asked why they elected not to use CPAS even though they had heard of it. The responses were that they did not know how to use the phone or the Internet $(27.6 \% ; n=543)$, they did not feel it was necessary (24.9\%; $n=489)$, and they hadn't found it practical $(17.8 \%$; $\mathrm{n}=35 \mathrm{I})$. In addition, they indicated that they didn't have time to use the system because they had decided to get examined at the last minute $(13.4 \% ; n=264)$, and replied that they had not used CPAS because of its cost $(10.5 \%$; $n=|| 4)$. Some $(5.8 \%$; $=|| 4)$ also said that the appointment list of their physician on CPAS was full. Informative and illustrative public service announcements spots could increase CPAS use. The Hello 182 phone line could also be made a free service.

Another striking result of our study is that though $78.8 \%$ had used CPAS before, only $49.9 \%$ used CPAS for the current appointment. Of those who did use CPAS, $28.4 \%$ made their appointment via the Internet and $71.6 \%$ used the Hello 182 phone line. In the study performed in Ankara, it was reported that of CPAS users, $58.33 \%$ in 2014 , $68.04 \%$ in 2015 , and $77.45 \%$ in 2016 later called Hello 182 to make appointments. Use of the phone line increased, while Internet use has declined. ${ }^{[4]}$ This may be because the phone is more practical, widespread, and accessible than the Internet. Furthermore, the phone operator may be able to help callers with problems. 
As members of the hospital staff are frequently asked by relatives to get appointments for them, we also asked about this. The practice takes up staff time and lowers the productivity of hospital personnel. In our study, $2.7 \%$ of the patients asked relatives working at the hospital for appointments. If we consider that every day, 7000 to 8000 patients are examined, the effect should not be underestimated. It has been evaluated as a nationwide problem that should be studied and addressed. Some measures relevant to these results have been taken in our hospital. For example, the online appointment program was removed. However, additional measures may decrease the rate of staff making appointments for relatives further.

Prolonged wait times in hospitals and in outpatient clinics have been studied for years. Research has indicated that longer waits have resulted in decreased satisfaction. In a study performed at Afyon State Hospital, the longest average wait, 58.12 minutes, was reported in the internal disease department, which also had the lowest satisfaction rate. Wait time and satisfaction level were found to be inversely correlated in other departments as well. In this study, the patients who came to the hospital after arranging their appointment beforehand had a shorter wait and greater satisfaction, while those who came without an appointment waited longer and were less satisfied. ${ }^{[13]}$ Our results indicated that the satisfaction level was highest in the internal medicine departments with shorter wait times. The patient satisfaction level was lower in the surgical departments and subspecialties. In this study, $46.5 \%$ of patients waited less than 15 minutes, $29.4 \%$ waited 15 to 30 minutes, $12.7 \%$ waited 30 to 60 minutes, $7.3 \%$ waited I to 2 hours, and $4.1 \%$ waited more than 2 hours for their examination. These rates are much better than those reported in other studies. Patients using CPAS had the shortest wait, while patients who used kiosks or acquaintances working at the hospital waited for longer periods. If rate of CPAS use increases, then large crowds, particularly those waiting in front of outpatient clinics in the morning, can be avoided and at the same time, the patient satisfaction rate would likely increase. To this end, explanations of how to use CPAS and the advantages it offers should be popularized using brochures, public service advertisements, etc. In addition, after an examination, an assistant or the physician might briefly inform the patient about CPAS and recommend its use.

CPAS use was higher in female patients vs. male, in married or single patients vs. widowed/divorced patients, and in white-collar workers vs. other occupational groups. CPAS use increased in parallel with increased income. Only a sight decrease in CPAS use was detected in patients with an income level $\geq T L 5000$. The rate of CPAS use was statistically significantly higher in patients living in the Konya city center and those coming from other cities when compared with local town or village residents.
Some $(27.6 \%)$ patients reported ignorance of how to make phone calls and/or use the Internet as the reason for not using CPAS. If we consider that $14.4 \%$ of the patients who presented at the hospital live in rural areas, nonuse of CPAS may stem from their lower socioeconomic level compared with those living in city centers. Patients coming a long way may make appointments beforehand out of concern of not having a chance to be examined.

Nearly half (48.3\%) of the patients who used a kiosk and $47.4 \%$ of the patients who asked the help of an acquaintance working at the hospital said that they would use this method the next time, and $92.2 \%$ of the patients who used CPAS indicated that they would use that method for their next visit. A statistically significant difference was found between these 2 groups of patients $(p<0.00 I)$. These outcomes demonstrate that patients are satisfied with CPAS and will use the same method the next time, while the patients who used a kiosk or an acquaintance were less satisfied and were less likely to use that method the next time. Shorter waiting periods and a greater probability of being examined by their preferred physician among CPAS users relative to the other 2 methods may affect patients' preferences favoring CPAS.

When the satisfaction levels of the patients were analyzed, $89.4 \%(n=639$ I) of all the participants in the survey said that the doctor spent sufficient time with them and that they were satisfied with the service they received. The highest satisfaction rate $(97.4 \%)$ was reported for dentistry, and the lowest $(76.4 \%)$ for the department of neurosurgery. Categorically, satisfaction rates were found to be $90.2 \%$ in the internal medicine group, $89.3 \%$ in the surgical group, and $88.0 \%$ in the subspecialties group. Satisfaction rates reported for some other university hospitals were as follows: Düzce University Hospital, 91.8\%; ${ }^{[14]}$ Gazi University Hospital, $85.5 \%$; $^{[15]}$ Marmara University Hospital, 64.5\%; ${ }^{[2]}$ Silvan State Hospital, 76.0\%; ${ }^{[16]}$ and Dicle University Hospital, $76.2 \% .{ }^{[17]}$ Only I of those hospitals had a better satisfaction rate than our hospital. It should also be noted that a larger number of patients are examined in our outpatient clinics than at many other hospitals. A high satisfaction rate despite a heavy patient load is thought to be related to the success of CPAS system and the achievement of providing easier, faster, and effective access into health services.

\section{Conclusion}

The majority $(88.7 \% ; n=6374)$ of the patients surveyed had heard of CPAS before, and 78.8\% $(n=5628)$ had used CPAS at least once. Awareness of CPAS is demonstrated in the number of the patients living in the center of the city $(80.5 \% ; n=4140)$, the district $(77.6 \% ; n=1009)$, local village or town $(63.6 \% ; n=274)$, and in another city $(77.7 \%$; $n=192$ ) who had used CPAS at least once. Half of the pa- 
tients made an appointment using CPAS, which indicates that this system is valuable. In addition, $92.2 \%$ of those who made an appointment using CPAS indicated that they would use the system again, which demonstrates that this system has largely been adopted by the public. More than half of the patients $(52.6 \%)$ who requested assistance with an appointment from an acquaintance at the hospital indicated that they wouldn't use that method for the next appointment, which was evaluated as a step toward institutionalization. Almost all $(89.4 \% ; n=6391)$ of the patients participating in the survey stated that the doctor spent adequate time with them and that they were satisfied with the service they had received. An increase in the rate of CPAS use is an important factor in decreasing outpatient waiting time and increasing patient satisfaction. In order to increase CPAS use, new strategies should be developed for patients of a lower socioeconomic level in rural areas. If use of the Hello 182 phone line can be provided free of charge, it may promote greater use of CPAS. Public service advertisements and and descriptive brochures should also be disseminated.

Ethics Committee Approval

The approval of the local Ethics Committee was obtained. Informed Consent

Approval was obtained from the patients.

Peer-review

Internally peer-reviewed.

Authorship Contributions

Concept: S.P., M.A.E., M.K.; Design: S.P., M.A.E., M.K.; Data collection \&/or processing: I.F.K.K., H.Y., S.M., D.K., I.S.; Analysis and/or interpretation: A.P.; Literature search: S.P.; Writing: S.P.; Critical review: M.A.E., M.K.

\section{Conflict of Interest}

None declared.

\section{REFERENCES}

1. Yıldırım HH, Yıldırım T. Avrupa Birliği Sağlık Politikaları ve Türkiye. Ankara: Sağllk-Sen Yayınları; 2011.
2. Önsüz MF, Topuzoğlu A, Cöbek U.C, Ertürk S, Yılmaz F, Birol S. İstanbul'da bir tıp fakültesi hastanesinde yatan hastaların memnuniyet düzeyi. Marmara Medical Journal 2008;21:33-4.

3. Merkezi Hekim Randevu Sistemi. Available at: https://www.mhrs. gov.tr/Vatandas/hakkimizda.xhtml. Accessed Apr 4, 2017.

4. Yıldızbaşı E, Öztaş D, Sanisoğlu Y, Fırat H, Yalçın N, Dağ Şeker E. Bir Eğitim ve Araştırma Hastanesinde Merkezi Hekim Randevu Sistemini Kullanan Hastaların Memnuniyet Düzeylerinin Ölçülmesi. Ankara Medical Journal 2016;16:293-302.

5. Erdem R, Rahman S, Avcı L, Demirel B, Köseoğlu S, Firat G, et al. Hasta Memnuniyetinin Hasta Bağlllığı Üzerine Etkisi. Erciyes Üniversitesi İktisadi ve İdari Bilimler Fakültesi Dergisi 2008;31:95-108.

6. Tezcan S, Altuntaş KH, Yeşildal N. Hacettepe Üniversitesi Ihsan Dogramacı Çocuk Hastanesi Polikliniklerine Başvuran Hastaların Hizmetlerden Memnuniyet Düzeyi. Hacettepe Tip Dergisi 1999;3:267-85.

7. Pala T, Saatl 1 G, Eser E. Hastanede yatan hastaların hastane hizmetleri ve hastane çalışanlarından memnuniyeti ve bunu oluşturan bileşenler. 8. Ulusal Halk Sağlığı Kongresi Bildiriler Kitabı. Diyarbakır; 2003. p. 538-41.

8. Pekten A. Genel Sağlık Sigortası Sistemi ve Getirdiği Yenilikler. Sayıştay Dergisi 2006;61:121.

9. Kılınç C. Bir Üniversite Hastanesinde Yatan Hastaların Tatmin Olma Düzeyleri. TAF Preventive Medicine Bulletin 2008;8:239-44.

10. Aslan Ş, Sezgin M, Haşloğlu SB. Özel sağlık kuruluşlarında müşteri memnuniyeti ve memnuniyeti oluşturan unsurların araştırılması. Muğla Üniversitesi Sosyal Bilimler Enstitüsü Dergisi 2008;20:24-40.

11. Carr-Hill RA. The measurement of patient satisfaction. J Public Health Med 1992;14:236-49.

12. Kavuncubaşı Ş. Hastane ve Sağlık Kurumları Yönetimi. Ankara: Siyasal Kitabevi; 2000. p. 292-5.

13. Karahan A, Gürpınar K. Hastanelerde kuyruk ve randevu sisteminin etkinliği üzerine bir araştırma: Afyon devlet hastanesi örneği. Sosyal Ekonomik Araştırmalar Dergisi 2009;9:155-72.

14. Aytar G, Yeşildal N. Yatan hasta memnuniyeti. Düzce Tip Fakültesi Dergisi 2004;3:10-4.

15. Yildırım A, Maral I, Aycan S, Bumin MA. Gazi Hastanesi yatakl servislerinde hizmet alanların bazı temel özelliklerine hastaneden memnuniyet durumları. Gazi Kalite Günleri II Bildiri Özet Kitabı Ankara; 1999. p. 71.

16. Özcan M, Özkaynak V, Toktaş İ. Silvan devlet hastanesine başvuran kişilerin memnuniyet düzeyleri. Dicle Tip Dergisi 2008;35:96-101.

17. Emhan A, Bez, Dülek Ö. Bir üniversite hastanesine başvuran hastaların memnuniyet düzeyleri. Dicle Tip Dergisi 2010;37:241-7.

\section{Merkezi Hekim Randevu Sistemi Kullanım Durumuna Etki Eden Faktörlerin Değerlendirilmesi}

Amaç: Bu çalışmadaki amacımız hastanemizde Merkezi Hekim Randevu Sistemi (MHRS) kullanım sıklı̆ı̆ı ve etki eden faktörleri araştırmaktır.

Gereç ve Yöntem: Çalışmaya 20 Ocak-28 Şubat 2017 tarihleri arasında hastanemiz polikliniklerine ayaktan başvurmuş ve muayenesi tamamlanmış 7187 kişi dahil edildi. Hastalarla tek tek yüz yüze görüşüldü ve anket uygulandı.

Bulgular: Tüm hastaların \%49.9'u MHRS'den, \%47.4'ü kiosklardan sıra aldığını söylemiştir. Mesleklerden MHRS kullanım oranı memurlarda; esnaf, işçi, ev hanımı ve emeklilere göre daha yüksek bulundu $(p<0.00 I)$. Eğitim seviyesi ve aylık gelir düzeyi arttıkça MHRS kullanım oranı da artmaktadır $(p<0.00 I)$. Konya merkezde oturanlarda kırsalda oturanlara göre MHRS kullanma oranı daha yüksekti $(p<0.00 \mathrm{I})$. Hastaların memnuniyet oranları \%89.4 olarak bulundu.

Sonuç: Merkezi Hekim Randevu Sistemi kullanımını artırmak için kırsaldan gelen, sosyokültürel seviyesi düşük olan hastalar için yeni stratejiler geliştirilmelidir. Mevcut olan kamu spotları ve tanıtıcı broşürler yaygınlaştırıımalıdır.

Anahtar Sözcükler: Alo 182; hasta memnuniyeti; merkezi hekim randevu sistemi; sıra bekleme. 